J. Lake Sci. (湖泊科学), $2007, \mathbf{1 9}(4): 413-420$

http://www. jlakes.org. E-mail: jlakes@ niglas. ac.cn

(c) 2007 by Journal of Lake Sciences

\title{
太湖流域汛期河湖等水位线的判读及其应用”
}

\author{
毛 锐, 李国砚, 刘晓玫 \\ (中国科学院南京地理与湖泊研究所,南京 210008)
}

\begin{abstract}
摘 要: 在中国湖泊-流域数据库的技术支撑下,绘制出太湖流域 20 世纪内 5 次 $(1931,1954,1983,1991,1999$ 年) 梅雨洪 水期,不同雨情、水情下的河湖等水位线. 以上述系列图幅为基础,解读了水情及水位发展过程,同时初步分析了等水位 线在防洪中的应用,以及新出现的太湖流域第三次水势演变等研究结果.
\end{abstract}

关键词: 太湖流域;等水位线;水势演变

\section{Isohath and its application of hydrologic situation during flood seasons in Taihu Basin}

\author{
MAO Rui, LI Guoyan \& LIU Xiaomei
}

( Nanjing Institute of Geography \& Limnology, CAS, Nanjing 210008, P. R. China)

\begin{abstract}
Based on lake-watershed database of china, the hydrologic situation figures of the five plum-floods in the 20 century were drafted out in this paper. i. e. the isohaths in five heavy flood, years $(1931,1954,1983,1991$ and 1999). The results indicated that isohaths wild be useful in the demonstration of hydrologic situation for flood control in recent years.
\end{abstract}

Keywords: Taihu Basin; Isohath; evolution of hydrologic situation

太湖流域河网密布, 具有通江达海, 内低周高之势.太湖流域地形自西向东微缓倾斜, 山地丘陵主要分 布在流域西部, 以 $10 \mathrm{~m}$ 等高线 (黄海高程)划分,西部山区面积 $7338.4 \mathrm{~km}^{2}$, 占流域面积的 $20 \%$; 平原主要 分布在流域的北部、东部和南部, 是太湖流域的主体,面积 $29556.5 \mathrm{~km}^{2}$,占流域面积的 $80 \%$. 在平原的周边 沿江、沿海地区为高程 5-12 m 的高平原, 而流域中部是以太湖为中心,包括淀泖、青松、嘉北在内的低洼地 区, 高程在 $4 \mathrm{~m}$ 以下,最低 $2 \mathrm{~m}$.

流域水文过程模拟是近年来深人认识流域水文过程的方法之一 ${ }^{[1,2]}$,而利用传统的地图信息与现代地 理信息技术相结合,解译更多的为流域管理所用的信息更是现代流域水资源管理所必须开展的研究工作. 太湖流域水系实为湖泊河网水系, 其水文站网历史悠久,尤其是本区水位站数量较多、分布均匀,再加上近 年来大多数水位站的水位基面和地面沉降都已订正 ${ }^{[3,4]}$, 因此有条件绘制出本区汛期较准确的水位等值线 (以下简称等水位线). 等水位线方法可用于进行流域防洪调度工作,同时也是研究全流域水势变化的一种 途径.

\section{1 影响本区水位传播和发展的主要因素}

\section{1 流域性的暴雨影响全区水位}

二十世纪几次流域性梅雨型暴雨引起全流域水位猛涨,如 1999 年 6 月 5 日 - 7 月 8 日,33 d 太湖 (西山 站) 水位涨幅 $2.06 \mathrm{~m}$, 日平均涨率达 $0.063 \mathrm{~m} / \mathrm{d}$, 日最大涨率 $0.22 \mathrm{~m} / \mathrm{d}(7$ 月 1 日). 同年河网水位从 6 月 7 日起涨, 7 月 1 日基本达到最高, 湖西、浙西、杭嘉湖区平原水位涨幅均在 $2.0 \mathrm{~m}$ 以上, 最大涨幅接近 $3.0 \mathrm{~m}$.

\section{2 地区性局部大强度、短历时的暴雨,也会造成地区高水位}

每年汛期下游区的水位主要由地区性暴雨控制; 因为流域性的暴雨洪水,经太湖调节及望虞河、太浦河

* 中国科学院南京地理与湖泊研究所知识创新工程 (CXNIGLAS-A01-1) 和所长专项基金项目 (S230032) 联合资助. 2006-04-17 收稿;2006-10-22 收修改稿. 毛锐, 男, 1937 年生, 研究员. 
排水,水位过程变缓,对下游水位变化影响不大. 此外,因下游区各片地势低洼平坦,再加上有太湖和众多 的湖荡水道调洪蓄水,洪枯水位变幅不大,正常年份最高,最低水位差只 $1 \mathrm{~m}$ 左右. 即 “高水不高, 低水不 低”的敏感水位区.

\section{3 江河湖海的水情变化对本区水位有明显的影响}

太湖流域地处我国沿江沿海的交汇处,三面濒江临海,长江横卧于流域之北; 东海位于流域之东;南部 为钱塘江杭州湾. 太湖水系有涵闸控制, 可引排水量进出长江; 南有长山闸可将涝水南排至杭州湾; 东部地 区还受到海潮倒灌、顶托的影响, 其范围可达上海、阳澄、淀泖及杭嘉湖大部分地区. 此外太湖本身在洪水 期, 因环湖大堤造成太湖水位抬高而产生回水,倒灌至长兴、吴兴、宜兴一线低洼地区. 通过以上分析可知, 江河湖海的水情对本区水位也有明显的影响.

影响水位传播和发展的因素,除降雨特征外,还与地形、流域水利工程建设、防洪调度方式及下垫面环 境变化等有关.

\section{2 等水位线的判读}

\section{1 水情}

在全国湖泊 - 流域数据库的支持下,绘制出太湖流域 $10 \mathrm{~m}$ 高程 (黄海基面) 以下平原区内,二十世纪五 次 (1931, 1954,1983,1991,1999 年) 梅雨型洪水期间等水位线 (以下简称等水位线), 水位系吴淞零点; 含涨 水、滞水、退水、倒灌、回水等水情, 以此系列图幅为基础,进行河湖等水位线的判读和分析. 图 1 显示各种 水情等水位线,说明见表 1 .


图 1 等水位线所显示的各种水情

Fig. 1 Isohath of Taihu Basin in different years

表 1 等水位线及相应的水情

Tab. 1 Isohath of Taihu and flood situation

\begin{tabular}{|c|c|c|c|c|}
\hline 图序 & a 梅雨太湖涨水 & $\mathrm{b}$ 雨止、太湖出流 & $\mathrm{b}$ 太湖回水 & $\mathrm{c}$ 长江倒灌 \\
\hline 等水位线日期 & 1983 年 7 月 9 日 & 1983 年 8 月 3 日 & 1983 年 8 月 3 日 & 1954 年 7 月 23 日 \\
\hline 等水位线 & 由湖西、浙西等水 & $3.5 \mathrm{~m} 、 3.0 \mathrm{~m}$ 二条 & 从 $3.8 \mathrm{~m}, 3.5 \mathrm{~m}$ 二 & 由 $5.0 \mathrm{~m}, 4.5 \mathrm{~m}$ 二 \\
\hline \multirow[t]{4}{*}{ 水情 } & 位线显示因上游梅 & 等水位线很接近, & 线可见太湖水位 & 条等水位线显示 \\
\hline & 雨量达 $360 \mathrm{~mm}$; 使 & 水位比降加大, 下 & 高于苕溪下游水 & 江水通过无锡梁 \\
\hline & 人湖水量猛增至 & 游排水通畅. 排水 & 位, 产生 回水倒 & 溪河倒灌至太湖. \\
\hline & $\begin{array}{l}1350 \mathrm{~m}^{3} / \mathrm{s} \text {; 太湖水 } \\
\text { 位上涨至 } 4.41 \mathrm{~m}\end{array}$ & $\begin{array}{l}\text { 主流线向长江、黄 } \\
\text { 浦江排水. }\end{array}$ & $\begin{array}{l}\text { 灌, } 8 \text { 月份有 } 28 \mathrm{~d} \\
\text { 倒灌. }\end{array}$ & \\
\hline
\end{tabular}

(增幅 $1.40 \mathrm{~m}$ ) 


\section{2 水位发展过程}

以 1991 年,1999 年两次大洪水为例, 从等水位线的变化判读二次洪水发展过程简述如下:

(1) 1991 年太湖流域洪水:该年人梅早,从 5 月 19 日开始到 7 月 13 日结束,梅雨期长达 $55 \mathrm{~d}$,酿成太湖 流域洪水为如下三次暴雨, 即 6 月 $11-14$ 日, 6 月 29-7月 13 日及 8 月 7 日前后三次暴雨,最大雨量中心 在江苏湖西区.

该年等水位线发展过程可分三个阶段:

涨水期 (6 月 11 日 - 6 月 28 日): 人梅前, 5 月太湖底水较高,约 $3.50 \mathrm{~m}$,第一次暴雨后上游湖西、浙西 区 $5.5 \mathrm{~m} 、 5.0 \mathrm{~m}$ 两条等水位线相近, 此时水位比降大, 汇人太湖流量达 $2450 \mathrm{~m}^{3} / \mathrm{s}(6$ 月 16 日), 太湖下游第 一条等水位线为 $4.0 \mathrm{~m}$,与太湖水位相近,下游排水困难,导致太湖水位与上游各片水位猛涨.

高峰期 (6月 29 日 - 7 月 16 日) : 上游湖西、浙西 $5.5 \mathrm{~m} 、 5.0 \mathrm{~m}$ 两条等水位线间距更小, 人湖水量仍较 大,达 $2200 \mathrm{~m}^{3} / \mathrm{s}$ (7 月 5 日), 而下游的水位差仍很小,太湖水位由 $4.12 \mathrm{~m}$ 升至 $4.78 \mathrm{~m}$.

退水期 (7月 17 日以后) : 上游等水位线间距加大, 人湖水量减少,下游等水位线间距变小,排水通畅. 7 月 16 日 -7 月 26 日太湖太浦闸泄水量由 $150 \mathrm{~m}^{3} / \mathrm{s}$ 增大至 $400 \mathrm{~m}^{3} / \mathrm{s}$, 使湖水水位稳步下降.

从等水位线图来看,湖东各条等水位线基本是南北向,主流向东,尽管当时太浦河尚未打通,黄浦江仍 是太湖地区排水主要通道.

(2) 1999 年太湖洪水:1999 年太湖流域 6 月 7 日人梅,7 月 20 日出梅,梅雨期长达 43 d. 集中降雨过程 有三段,分别为 6月 7-11日,6月 15-17日,6月 23日 - 7 月 1 日,流域南片、下游地区均达到大暴雨,致 使流域发生 20 世纪以来最大一次洪水.

该年等水位线的发展过程仍可分三阶段:

涨水期 (6月 11 日 - 6 月 28 日) : 人梅前整个太湖流域河网湖泊水位较低,太湖水位不到 $3.0 \mathrm{~m}$, 大暴雨 后上游长兴平原、湖西山区等水位线很陡, $5.0 \mathrm{~m} 、 4.5 \mathrm{~m}$, 等水位线间隔小、坡度大, 人湖水量猛增, 最高达 $3089 \mathrm{~m}^{3} / \mathrm{s}$ ( 6 月 28 日), 同时下游水位平缓,太湖与阳澄区水位相近,无法排水,太湖 “纳而不吐”, 水位猛增 至 $4.2 \mathrm{~m}$.

高峰期 (6 月 29 日 - 7 月 8 日): $5.5 \mathrm{~m}$ 等水位线西移,上游 $5.5 \mathrm{~m}$ 与 $5.0 \mathrm{~m}$ 两条等水位线间隔逐渐拉 大、水位差缩小、入湖水量下降, 7 月 8 日为 $1059 \mathrm{~m}^{3} / \mathrm{s}$, 太湖下泄仍不畅, 水位上升最高为 $4.98 \mathrm{~m}(7$ 月 8 日).

退水期 (7 月 8 日以后):太湖下游等水位线密度加大,特别是 $4.5 \mathrm{~m} 、 4.0 \mathrm{~m}$ 两条等水位线间距很小, 并 偏向湖东岸, 利于两河 (望虞河、太浦河) 开闸放水,上游人湖流量也降至 $100 \mathrm{~m}^{3} / \mathrm{s}$ ( 7 月 17 日),7月 18 日太 湖闸最大泄量达 $799 \mathrm{~m}^{3} / \mathrm{s}$.

全区等水位线是南北向,主流为东,此时太浦河已打通,南排工程已竣工,出现沿江,太浦河、望虞河,南 排工程三个方向排水.

\section{3 等水位线的判读在防洪调度中的应用}

\section{1 确定最佳的开闸时机}

环太湖已建成望虞河望亭水利枢纽,及太浦河太浦闸,并在江苏段 98 处口门,浙江段 28 口门先后建 闸. 据 1999 年太湖流域管理局调度方案(望亭水利枢纽及太浦闸的运行方式根据当时流域具体雨情、水情 而定. 环太湖其他闸门的调度原则是: 武澄锡虞环湖闸门可根据无锡水位决定闸门启闭; 苏州环湖闸门根 据枫桥水位决定闸门启闭;杭嘉湖环湖闸门根据双林水位决定闸门启闭.

1987 年 “太湖流域综合治理总体规划方案”提出控制太浦河平望水位为 $3.30 \mathrm{~m}$, 它关系到太浦闸的启 闭,但这一水位涉及到省际间防洪利害关系, 难于实施. 我们认为以一站水位决定太浦闸的启闭尚不够充 分,建议可根据当时太湖上下游等水位线的变化趋势来运作.

3.1 .1 不利的开闸条件 在太湖出现超标准洪水期间,为尽快降低太湖水位,应充分利用太浦闸和望亭水 
利枢纽向下游泄洪,但遇到下列情况则不利开闸：

(1) 1997 年 7 月 3 日太湖排水时,太湖高水位与下游阳澄、淀泖、杭嘉湖区水位相差无几 (图 2a).下游 $4.5 \mathrm{~m}, 4.0 \mathrm{~m}$ 两条水位线在淀泖, 杭嘉湖一带, 间距大,太湖与下游水位持平, 阻碍太浦河行洪 ${ }^{[3]}$.

(2) 太湖排水时遇到下游出现天文高潮,则要进行泄量控制.

如 1999 年 7 月 14 日, 15 日正逢农历初二,初三天文大潮,因此太浦闸泄洪就要避开这两天早上高潮对 太湖泄量控制. ${ }^{[2]}$

(3) 太湖排水时,下游出现大暴雨,抬高了下游河湖水位,此时也不利排水.

如 1991 年 8 月 7 日, 江阴青阳站降雨 $137 \mathrm{~mm} / \mathrm{d}$, 蕴藻浜站降雨 $240.5 \mathrm{~mm} / \mathrm{d}$, 许多河道水位上涨 0.43 $\mathrm{m} / \mathrm{d}$ (无锡) , $0.74 \mathrm{~m} / \mathrm{d}$ (青阳) 致使该区水位从 $3.9 \mathrm{~m}$ 升至 $4.5 \mathrm{~m}^{[3]}$, 而此时太湖水位仅 $4.25 \mathrm{~m}$, 无法泄洪.

(4) 1999 年分区排水后,往往在太湖排水时出现洪涝矛盾,地区性涝水争先占据了望虞河及太浦河排 洪通道,太湖洪水无法下泄,这也是不利泄洪条件.

3.1 .2 开闸泄洪的最佳时期 (1) 当太湖水位涨到顶峰, 雨止而且人湖量减少, 太湖与下游水位水头差增 大, 则可开闸泄洪. 如图 $2 \mathrm{~b}$ 所示, $4.5 \mathrm{~m}$ 与 $4.0 \mathrm{~m}$ 两根等水位线间距变小, 等水位线密度加大, 出现明显的 落差,此时有利太浦河望虞河二闸开闸泄洪.

(2) 出现天文低潮时,下游河湖水位普遍降低,有利于开闸放水.
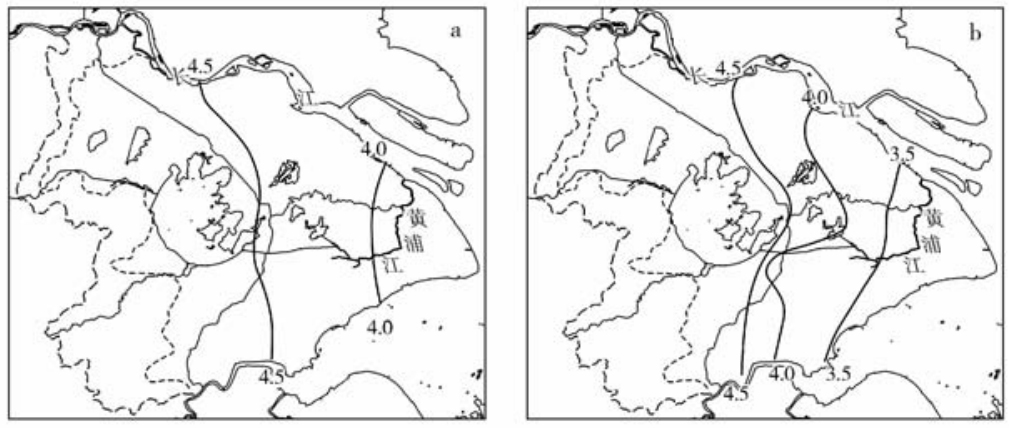

图 2 环太湖闸门开启时机 ( $\mathrm{a}$ :不利于开闸 1999 年 7 月 3 日; b: 有利于开闸 1999 年 7 月 8 日)

Fig. 2 Condition of opening of the gates around Lake Taihu(a. not suited for opening; b. suited for opening)

\section{2 绘制出洪涝灾害淹没范围图}

以太湖流域汛期最高水位时等水位线,与太湖流域地面高程图或地形图上地形点相比,并参考圩区分 布及圩堤高度即可绘出地面积水深度范围图. 再进行实地访问调查进行修正后, 可绘出洪水淹没范围图, 1991 年, 1999 年太湖流域淹没范围图 ${ }^{[5]}$, 根据上述方法绘制.

\section{3 平原区和太湖水位的峰值的关系}

太湖流域梅雨期往往出现一场接一场的大暴雨过程,促使太湖流域平原区和太湖水位猛涨,为分析平 原区和太湖两水位峰值的定量关系, 将选定太湖平原区 18 座水位站 ${ }^{1}$ 和环太湖 5 座水位站的均值为代表, 进行统计计算, 分析结果如下:

(1) 两水位峰值定量关系

上世纪五十年代和九十年代梅雨期太湖流域平原区和太湖平均水位峰值的关系是不同的,上世纪五十 年代梅雨期平原区水位若增高 $1 \mathrm{~m}$, 而太湖同期水位只增高 $0.3 \mathrm{~m}$; 而到上世纪九十年代平原区水位增高 1 $\mathrm{m}$,太湖水位也同步增高 $1 \mathrm{~m}$, 水位增速成倍的增加. 相同之处是上世纪五十年代和九十年代梅雨期当平原 区水位增长 $1 \mathrm{~m}$ 后,太湖水位增速平缓.

(1)太湖流域平原区 18 站为宜兴、琳桥、苏州、平望、无锡、杭长桥、长兴、新市、湖州、(距湖岸 $30 \mathrm{~km}$ 以内); 溧阳、常 州、湘城、常熟、昆山、甘露、德清、范家村、嘉兴(距湖岸超过 $30 \mathrm{~km}$ ). 
(2) 两水位峰值出现的时间差

上世纪五十年代梅雨期平原区水位峰值出现 $13 \mathrm{~d}$ 后, 太湖水位才相应出现峰值; 而上世纪九十年代平 原区水位峰值出现 6-8d 后,太湖水位即出现峰值(表 2).

(3) 平原区平均水位峰值与人太湖流量的关系

汛期人湖最大流量出现的时间往往早于上游平原区水位峰值出现时间 $1-2$ 日.

总结以上分析, 即梅雨期现今太湖水位增速比上世纪五十年代加快, 太湖水位峰值也逐渐增高, 这样促 使太湖防洪形势严峻.

表 2 两水位峰值出现时间比较

Tab. 2 Comparing of period when the peak value occurred in Lake Taihu and flood plain

\begin{tabular}{|c|c|c|c|c|c|}
\hline \multirow{2}{*}{ 年份 } & \multicolumn{2}{|c|}{ 平原区 18 座水位站平均水位 } & \multicolumn{2}{|c|}{ 环太湖 5 座水位站平均水位 } & \multirow{2}{*}{$\begin{array}{l}\text { 两处平均水位峰 } \\
\text { 值的时间差 (日) }\end{array}$} \\
\hline & 水位峰值 $(\mathrm{m})$ & 时间 (月.日) & 水位峰值 $(\mathrm{m})$ & 时间 (月.日) & \\
\hline 1983 & 4.65 & 7.6 & 4.41 & 7.11 & 6 \\
\hline 1991 & 4.46 & 6.16 & 4.27 & 6.23 & 8 \\
\hline 1999 & 5.10 & 7.1 & 4.97 & 7.8 & 8 \\
\hline 1954 & 4.86 & 7.12 & 4.68 & 7.24 & 13 \\
\hline
\end{tabular}

\section{4 太湖流域平原区水位代表站的选定}

太湖流域平原区水位站和潮位站共有 130 余座, 根据大量的等水位线资料分析,选出其中 32 站作为汛 期水位代表站 (表 3, 表 4). 其条件为: (1) 能反映主要河湖的水位变化的水位控制点,并且是构成水网的主 要节点; (2) 水位站资料系列长和周边水位站水位资料有稳定关系; (3) 主要水利设施及省际边界的水 位站.

表 3 水位、潮位代表站

Tab. 3 Nane of station in different regions

\begin{tabular}{ccccccc}
\hline 湖区 & 湖西 & 武澄夕虞区 & 阳澄淀泖区 & 杭嘉湖区 & 长江杭州湾感潮区 \\
\hline 大浦口 & 金坛、宜兴 & 无锡 & 苏州、昆山 & 嘉兴、长兴 & 镇江 & 芦潮港 \\
西山 & 王母观 & 青阳 & 平望 & 新市、范家村 & 江阴 & 乍浦 \\
望亭 $($ 太 $)$ & 坊前 & 甘露(望) & 湘城 & 双林 & 浒浦 & 澉浦 \\
小梅口 & 常州 & 琳桥 & 芦墟 & 湖州 & 杨林 & 盐官 \\
夹浦 & 溧阳 & & 枫桥 & 王江㳗 & 吴淞 & \\
\hline
\end{tabular}

\section{4 根据等水位线来分析太湖流域水势的变化}

\section{1 近年来上游地区的河湖出现“中雨高水”的水情}

20 世纪末期和中期相比, 若只比较梅雨量, 不考虑其他降雨特征, 则在相同梅雨量时湖西和浙西区都 新增一条高出 $0.5 \mathrm{~m}$ 等水位线. 如图 $3 \mathrm{a}, \mathrm{b}$ 中可见浙西区在相同梅雨量时 1931 年只有 $6.0 \mathrm{~m}, 5.5 \mathrm{~m}, 5.0 \mathrm{~m}$, 三条等水位线,而 1999 年却有 $6.5 \mathrm{~m}, 6.0 \mathrm{~m}, 5.5 \mathrm{~m}, 5.0 \mathrm{~m}$ 四条等水位线. 在图 $3 \mathrm{c}, \mathrm{d}$ 中可见湖西区在相同梅 雨量时, 1954 年只有 $5.0 \mathrm{~m}, 4.5 \mathrm{~m}$ 两条等水位线; 而 1991 年却出现 $5.5 \mathrm{~m}, 5.0 \mathrm{~m}, 4.5 \mathrm{~m}$ 三条等水位线. 同 样梅雨量现今上游地区河湖水位上涨量增加 $0.5 \mathrm{~m}$ 以上. 导致水位上升率提高的最主要原因是因建国后 上游区进行圩区建设和湖泊围星使圩外水面积减少 $305 \mathrm{~km}^{2}$ (1990与 1964 年相比) ${ }^{[6]}$. 减少河湖调蓄量约 $6.1 \times 10^{8} \mathrm{~m}^{3}$, 使上游区现今水位上升率增加 $10 \%-30 \%$.

\section{2 治理前后太湖下游由“二向排水”变成“三向排水”}

垂直于等水位线的主流线,即水流的总流势,我们选择 1954 年 9 月 14 日 (治理前) 和 1999 年 7 月 18 日 (治理后) 进行比较,这两天太湖排水时等水位线基本都是南北向,主流向东,符合地形,总水势未变. 不 
同点是治理前下游二向排水 (黄浦江, 长江), 而治理后下游增加了南排杭州湾形成三向排水 (黄浦江, 长 江, 杭州湾).

表 4 水位代表站最高水位 ${ }^{*}$

Tab. 4 Highest water level in different stations

\begin{tabular}{|c|c|c|c|c|c|c|c|c|c|c|c|c|}
\hline \multirow[b]{2}{*}{ 站名 } & \multicolumn{2}{|c|}{ 历史最高 } & \multicolumn{2}{|c|}{1931 年 } & \multicolumn{2}{|c|}{1954 年 } & \multicolumn{2}{|c|}{1983 年 } & \multicolumn{2}{|c|}{1991 年 } & \multicolumn{2}{|c|}{1999 年 } \\
\hline & $\begin{array}{l}\text { 水位 } \\
(\mathrm{m})\end{array}$ & $\begin{array}{c}\text { 时间 } \\
\text { (年.月.日) }\end{array}$ & $\begin{array}{l}\text { 水位 } \\
(\mathrm{m})\end{array}$ & $\begin{array}{l}\text { 时间 } \\
\text { 月.日) }\end{array}$ & $\begin{array}{l}\text { 水位 } \\
(\mathrm{m})(\end{array}$ & $\begin{array}{l}\text { 时间 } \\
\text { 月.日) }\end{array}$ & $\begin{array}{l}\text { 水位 } \\
(\mathrm{m})(\end{array}$ & $\begin{array}{l}\text { 时间 } \\
\text { 月.日） }\end{array}$ & $\begin{array}{l}\text { 水位 } \\
(\mathrm{m}) \text { ( }\end{array}$ & $\begin{array}{l}\text { 时间 } \\
\text { 月. 日 ) }\end{array}$ & $\begin{array}{l}\text { 水位 } \\
(\mathrm{m})\end{array}$ & $\begin{array}{l}\text { 时间 } \\
\text { 月. 日 ) }\end{array}$ \\
\hline 太湖 & 4.97 & 1999.7 .08 & 4.50 & 8.01 & 4.65 & 7.31 & 4.43 & 7.19 & 4.79 & 7.14 & 4.97 & 7.08 \\
\hline 常州 & 5.59 & 1931.7 .25 & 5.59 & 7.25 & 5.24 & 7.23 & 4.80 & 7.05 & 5.53 & 7.02 & 5.48 & 6.28 \\
\hline 无锡 & 4. 87 & 1991.7 .02 & 4.70 & 8.11 & 4.73 & 7.28 & 4.44 & 7. 18 & 4.87 & 7.02 & 4.74 & 7.01 \\
\hline 苏州 & 4. 57 & 1999.7 .01 & 3.97 & 7.30 & 4.37 & 7.28 & 3.76 & 7.06 & 4.31 & 7.05 & 4.57 & 7.01 \\
\hline 平望 & 4. 40 & 1999.7 .03 & 4.04 & 7.31 & 4.35 & 8.02 & 3.90 & 7.06 & 4.17 & 7.07 & 4.40 & 7.03 \\
\hline 嘉兴 & 4.37 & 1954.7 .31 & 3.86 & 7.30 & 4.37 & 7.31 & 4.11 & 7.06 & 4.05 & 7.06 & 4.34 & 7.01 \\
\hline 杭长桥 & 5.61 & 1951.7 .18 & 5.15 & 9.07 & 5.63 & 5.21 & 5.45 & 7.06 & 5.35 & 7.06 & 5.60 & 7.01 \\
\hline 望亭 & 5.00 & 1999.7 .09 & 4.35 & 7.24 & 4. 42 & 7.28 & 4.61 & 7.13 & 4.82 & 7.15 & 5.00 & 7.09 \\
\hline 大浦口 & 5.08 & 1999.7 .06 & 4.73 & - & 4.63 & 8.04 & 4.73 & 8.04 & 5.01 & 7.14 & 5.08 & 7.06 \\
\hline 常熟 & 4.26 & 1954.7 .24 & 3.97 & 7.26 & 4.26 & 7.24 & 3.63 & 7.05 & 4.23 & 7.04 & 4.23 & 7.01 \\
\hline 丹阳 & 7.63 & 1931.7 .14 & 7.63 & 7.14 & 7.42 & 7.23 & 5.90 & 6.21 & 7.33 & 6.14 & 6.57 & 6.28 \\
\hline 溧阳 & 6.00 & 1991.7 .08 & 5.50 & - & 5.41 & 7.12 & 5.23 & 7.05 & 6.00 & 7.08 & 5.98 & 7.01 \\
\hline 西山 & 5.00 & 1999.7 .08 & - & - & 4.73 & 7.28 & 4.43 & 7.16 & 4.94 & 7.13 & 5.00 & 7.08 \\
\hline
\end{tabular}

* 部分资料参考文献 $[3]$ 、[4].

由表 5 可见,太湖流域“11 项工程”实施后,新辟“南排工程”,使治理后恢复了排水入杭州湾的通道,形 成三向排水格局. 其各向排水量发生变化 (表 5 ).

\section{3 太湖下游水势第三次演变开始}

太湖流域是一个复杂的水网系统, 河道纵横, 湖泊棋布, 河道总长约 $120000 \mathrm{~km}$, 河道分布密布 $3.24 \mathrm{~km} /$ $\mathrm{km}^{2[7]}$, 很多水网区都是每隔几百米即有一条河道的江南水乡. 太湖水系开发很早, 远在春秋战国之前, 已 载有,其上游水系变化不大,泄水河道有网少纲. 建国初期下游骨干河道,仅有武澄锡区通江 4 河, 阳澄地 区通江 5 河, 黄浦江及上海地区通江达海近 10 条河流, 仍缺少骨干河流, 所以排洪能力差. 对于太湖流域 下游这复杂的水网系统, 可通过分析等水位线的变化来研究其历年来水势的演变. 水势即水网流向的归纳 和综合, 它与地形、河相、水量等因素有关. 地形决定总的流向, 但河网的网格、尺寸及不断变化着的水量也 决定了排水的格局,垂直于等水位线的主流线,可显示出排水方向. 如从图 $4 \mathrm{a}, \mathrm{b}$ 中主流线方向变化中可明 显看出 20 世纪末期已由原来两向排水演变为三向排水,由表 5 可见其各排水方向水量比例也在变化.

表 51954 年, 1999 年 $5-7$ 月太湖流域出流水量比例

Tab. 5 Quantity of water runout of Taihu Basin in 1954 and 1999

\begin{tabular}{|c|c|c|c|c|c|c|}
\hline \multirow{2}{*}{ 时间 } & \multirow{2}{*}{ 项目 } & \multicolumn{2}{|c|}{ 人长江 } & \multirow{2}{*}{ 人杭州湾 } & \multirow{2}{*}{ 进黄浦江 } & \multirow{2}{*}{ 总出流 } \\
\hline & & 总量 & 其中湖西区 & & & \\
\hline \multirow[t]{2}{*}{1954 年 $5-7$ 月 } & 水量 $\left(\times 10^{8} \mathrm{~m}^{3}\right)$ & 12.66 & -3.20 & 0.0 & 87.80 & 100.46 \\
\hline & 百分比 & 12.60 & & 0.0 & 87.40 & 100.00 \\
\hline \multirow{2}{*}{$\begin{array}{c}1999 \text { 年 } 6 \text { 月 } 7 \text { 日 - } \\
7 \text { 月 } 7 \text { 日 }\end{array}$} & 水量 $\left(\times 10^{8} \mathrm{~m}^{3}\right)$ & 33.45 & & 11.69 & 28.55 & 73.69 \\
\hline & 百分比 & 45.39 & & 15.86 & 38.75 & 100.00 \\
\hline
\end{tabular}





图 3 相同梅雨量不同年份等水位线比较 $\mathrm{a}: 1931$ 年 8 月 1 日 (浙西累积梅雨量 $720 \mathrm{~mm}$ ) ; b : 1999 年 6 月 30 日 (浙西累积梅雨量 $687 \mathrm{~mm}$ ); $\mathrm{c}: 1954$ 年 7 月 18 日 (浙西累积梅雨量 $460 \mathrm{~mm}$ ) ; d:1991 年 6 月 18 日 (浙西累积梅雨量 $411 \mathrm{~mm}$ )

Fig. 3 Isohathes with some plum raining in different years
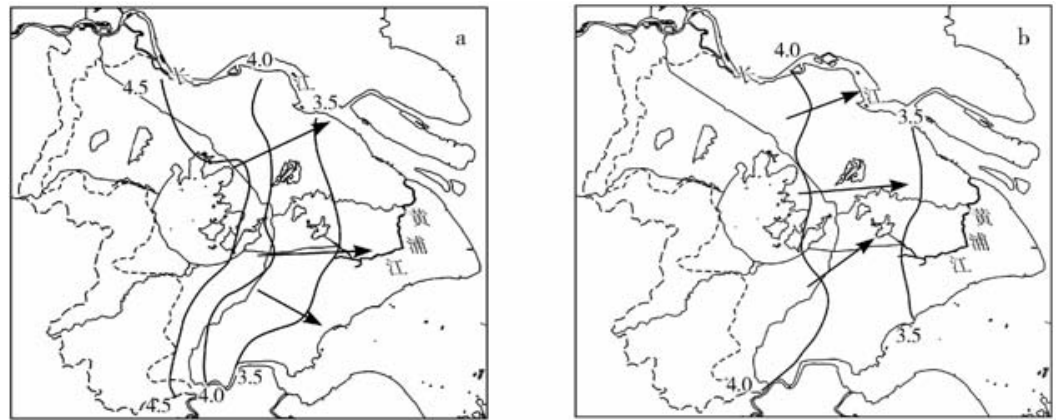

图 4 治理前后下游区等水位线的变化( $\mathrm{a}: 1999$ 年 7 月 18 日; b:1954 年 9 月 14 日)

Fig. 4 Isohath before and often improving in lower reaches of Taihu Basin

20 世纪末水势的改变, 将不同于历史上已出现第一次, 第二次水势的改变, 第一、二次水势改变简述 如下:

(1) 第一次太湖下游水系的演变在唐宋时期“东娄湮废,湖界形成”. 在 3000 年前太湖形成不久,太湖 下游是一片 “白水”, 湖界不明确, 传说有娄、淞、东三江向东, 北, 南三向排水水路既短又畅, 迅速人海. 而到 了 8-12 世纪唐宋期间, 海岸线向外伸长, 导致东、娄二江. 相继湮废, 由东南和东北通江通海的七十二浦 
替代二江. 此时段又修筑了苏州至平望的塘路和长桥, 使太湖东岸湖界形成, 从此太湖排水受阻, 吴淞江 萎缩.

(2) 第二次太湖下游水系演变在明清时期 “南北分流,黄埔夺淞”. 明永乐元年 (1403 年) 夏元吉治水, 以采用南北分流来代替拓浚吴淞江的方案, 向北面发展挚淞人汶河; 同时在南面又疏浚扩展范家浜. 开通 范家浜后, 因纳浙西、杭嘉湖及微山湖来水, 水量大增, 最后出现黄埔夺淞, 一江泄水为主的局面. 东南诸 港, 自明中叶以后东南出海全部封闭,这是历史上太湖下游水系的突变,形成了黄浦江.

第三次太湖下游水系演变,在建国后二十世纪末 “二河一线,三向排水”. “11 项治太工程” 实施后,建 成 “两河一线” 的流域蓄洪系统, 并形成了以太浦河、望虞河、黄浦江、武澄夕西线河道, 东苔溪导流港等河 道, 分隔了湖西、澄夕虞、阳澄、浦西、浦东及杭嘉湖等六个分区. 这些水利分区之间已建成控制线,可进行 人工调控. 同时在南部杭州湾增辟了 4 个排水闸和 1 座洜站,使整个河势发生很大变化. 从等水位线可看 出其突出的变化应是出现了三向排水. 东北、东、南三个方向排水, 它又不同历史上 “三江排水”, 因古代三 江只是初期河型,而现今已能被人工调控; 其次是控制线分隔成六大水利分区,自排区域内涝水,也就是向 北排水区域被分割 ${ }^{[7]}$.

上述三次水系演变大都是在人文驱动下形成,第一次是在太湖东岸兴建湖岸; 第二次是南北分流,开通 范家浜;第三次是十一项治太工程后,由此形成新的水势格局. 历史是一面镜子,可为认识现代提供有益的 借鉴.

\section{5 参考文献}

[1] 高俊峰, 问国年. 基于地图计算的流域水文过程模拟一一太湖流域上游西苕溪流域为例. 湖泊科 学,2005,17(4):305-310.

[2] 高俊峰, 问国年, 赵广举等. 流域数据模型研究——太湖流域西苕溪流域为例. 湖泊科学, 2006, 18 (3) :312-318.

[3] 吴浩云等. 1991 年太湖流域洪水. 北京: 中国水利水电出版社,2000:146-148.

[4]《1999 年太湖流域洪水》编委会. 1999 年太湖流域洪水. 北京: 中国水利水电出版社,2000:71-72.

[5] 毛 锐. 建国以来太湖流域三次大洪水的比较及对今后治理洪涝的意见. 湖泊科学, 2000,12(1):14 -15 .

[6] 余之祥. 长江三角洲水资源与区域发展. 合肥:中国科学技术大学出版社, 1997:76.

[7] 黄宣伟. 太湖流域规划与综合治理. 北京: 中国水利水电出版社, $2000: 49,231$. 